European Journal of Pragmatism and American Philosophy

VIII-1 | 2016

Dewey's Democracy and Education as a Source of and a Resource for European Educational Theory and Practice

\title{
George Herbert Mead and the Unity of the Self
}

\section{Mitchell Aboulafia}

\section{(2) OpenEdition}

\section{Journals}

Electronic version

URL: http://journals.openedition.org/ejpap/465

DOI: 10.4000/ejpap.465

ISSN: 2036-4091

\section{Publisher}

Associazione Pragma

\section{Electronic reference}

Mitchell Aboulafia, « George Herbert Mead and the Unity of the Self », European Journal of Pragmatism and American Philosophy [Online], VIII-1 | 2016, Online since 20 July 2016, connection on 10 December 2020. URL : http://journals.openedition.org/ejpap/465 ; DOI : https://doi.org/10.4000/ejpap.465

This text was automatically generated on 10 December 2020.

\section{c) $(7) \Theta$}

Author retains copyright and grants the European Journal of Pragmatism and American Philosophy right of first publication with the work simultaneously licensed under a Creative Commons AttributionNonCommercial-NoDerivatives 4.0 International License. 


\title{
George Herbert Mead and the Unity of the Self
}

\author{
Mitchell Aboulafia
}

George Herbert Mead failed to make his mark with a singular account of the self. In part this was due to the fact that he never published a book on the topic, only a limited number of articles. His most important book on the subject, Mind, Self, and Society: from the Standpoint of a Social Behaviorist, was edited and published posthumously, and based on student notes. ${ }^{1}$ But this only begins to address the problem. Although we will never know if Mead would have carefully clarified his use of the term "self" in a monograph, we do know that the term has different meanings in the works that are available. Some of these usages can be explained by context and present only minimal difficulties of interpretation. Unfortunately, this is not always the case. There are genuine tensions and challenging questions about the ways in which the term is employed. Mead, for instance, thought that the self must involve some sort of unity, the most famous example of which is the unified self that arises in relationship to a generalized other. However, even here questions immediately arise, for one wants to know how the selves of different generalized others relate to each other, especially given the fact that generalized others differ in their range, complexity, and levels of abstraction. Do more comprehensive generalized others preserve the integrity of the selves of their less encompassing brethren or do they undermine their character?

2 I will be exploring Mead's various uses of the term self. ${ }^{2}$ I do not believe that we will ever be in a position to provide a univocal definition, if only because Mead himself appears to accept the fact that there are contexts in which the word can and should be used differently. There is, however, an overarching vision that ties his most innovative uses of the term together, including the manner in which he thinks about systems as open systems. But in addition to Mead the theorist of systems and novelty, there is also the Mead who assumes that narrative plays a significant role in unifying the self, although this aspect of Mead's thought remains almost entirely implicit. Mead's dependence on a 
notion of narrative can help explain why he so often assumes that there is a unity to the self without making the grounds for this unity explicit.

Two questions guide this examination of Mead's ideas: what kinds of unity or continuity are characteristic of selves? And is there a form of unity - a "meta-self" - that can encompass the types of selves that we find in Mead? In response to the second question, I demonstrate that Mead had a narrative account of the self, one that has the potential to incorporate different kinds of selves, although Mead left his account underdeveloped. A methodological point before addressing the questions at hand: This article tries to provide a plausible account of how we might understand the unity of the self for Mead. In doing so it draws on a range of his writings and lectures from approximately the last two decades of his life. It is perhaps best understood as a piece of detective work. The clues are the various ways Mead spoke about the self in his lectures and writings. However, because there is no authoritative edition of his collected works - for example, questions have been raised about the accuracy of the presentation of his ideas in the edited lectures - and because Mead's language can be imprecise, there is no final verdict regarding the questions at hand, although I have sought to minimize the chance of a misreading by appealing to ideas that recur in Mead's work.

\section{米}

Let us assume that we have an obligation to keep our promises. Let us also assume that the notions of self-assertion, self-respect, and self-realization can have meaning even if one does not believe in an essential self, a substantive self, or a soul. We will accept these claims for the present because George Herbert Mead supports them.
It is interesting to go back into one's inner consciousness and pick out what it is that we are apt to depend upon in maintaining our self-respect. There are, of course, profound and solid foundations. One does keep his word, meet his obligations; and that provides a basis for self-respect. But those are characters which obtain in most of the members of the community with whom we have to do. We all fall down at certain points, but on the whole we always are people of our words. We do belong to the community and our self-respect depends on our recognition of ourselves as such self-respecting individuals. But that is not enough for us, since we want to recognize ourselves in our differences from other persons. [...] [T] here is a demand, a constant demand, to realize one's self in some sort of superiority over those about us. (MSS: 204-5)

Who or what self seeks to realize him or herself in this fashion? It is not at all obvious how Mead would address this question, and this is no small matter. In this passage we find references to self-realization, self-respect, self-assertion, and the keeping of promises. But what self is realizing itself, what self is an object or subject of self-respect, what self tries to outshine others, what self knows that failing to keep a promise is wrong? Is it the same self at any given time? For Mead, individuals can have multiple social selves, which are linked to groups and communities. Is there a unity or continuity to the self, a type of meta-self, that transcends these social selves, and if so, how are we to understand it?

Perhaps trying to locate any sort of meta or comprehensive self in Mead - one who might find the breaking of promises a violation of his or her integrity - is simply wrongheaded. Mead's use of the term self has given rise to something of a cottage industry that seeks to explain what the self truly is for Mead. After seventy-five years of Mead scholarship 
maybe it is time to cease trying to determine what Mead really meant by the term self, let alone whether there is a type of meta-self. For example, we know that the self is often a social and cognizable object, the "me." At other times it is the combination of the conventional "me" and the impulsive and spontaneous "I." Mead is often emphatic about how the self excludes the body, because the self is a cognizable social object. But then he is willing to speak of an unconscious self, which is made up of bundles of habits, and we know that habits are closely linked to bodily dispositions. ${ }^{5}$ Mead also tells us that, "As a mere organization of habit the self is not self-conscious. It is this self which we refer to as character." 6

7 It is possible that in using the term self in a variety of ways Mead may have been taking his cue from William James. ${ }^{7}$ In the Principles of Psychology James describes different types of selves: "The constituents of the Self may be divided into two classes, those which make up respectively - (a) The material Self; (b) The social Self; (c) The spiritual Self; and (d) The pure Ego." ${ }^{8}$ There is, however, one very significant difference between James and Mead. James's account of the self or selves is carefully articulated in one of the most influential books in psychology and philosophy of the nineteenth century. Mead's usages are spread over a corpus of published and unpublished works, and discovering all of them seems to require the efforts of a Sherlock Holmes. (Ah, Mr. Mead, caught yet again with another self!)

8 However, the fact that Mead used the term in different ways does not undermine the possibility that he may have had a notion of a meta or comprehensive self. As a matter of fact, his willingness to use the term self in so many ways argues for leaving the door open to this possibility. It would be difficult to appreciate his commitment to self-realization and self-assertion, for example, if we were to restrict their relevance to selves that exist only in relationship to specific communities. ${ }^{9}$ Nor would limiting these notions to the domain of the impulsive and spontaneous "I" do justice to the ways in which Mead employs them. These notions, and others that we will encounter, appear to point to a self that eludes definition solely in terms of the particularity of specific communities, even large ones, and the spontaneity of the "I."

9 In my view, Mead was not fully successful in articulating the nature of a meta or comprehensive self, although his insights are fertile, which is one reason why his thought is still vital. Mead, for example, has the potential to assist those seeking to reinvigorate and rethink sentiment theory and the role of empathy in moral development, as well as to challenge simulation theorists. ${ }^{10}$ Through Mead's sensitivity to the ways in which sociality informs self development his work can complement well-known narrative accounts of the self in thinkers such as Hannah Arendt, Alasdair MacIntyre, and Charles Taylor. It can also complement these accounts because narrative, as we shall see, is an important feature of Mead's understanding of the self, although he focuses more attention on the intersection of behavior and ontogenesis than these thinkers. But before turning to a discussion of narrative, we need to clarify further Mead's concerns and his notions about the self.

Dewey tells us in his "Prefatory Remarks" to the Philosophy of the Present that, "When I first came to know Mr. Mead, well over forty years ago, the dominant problem in his mind concerned the nature of consciousness as personal and private." ${ }^{11}$ But Mead was not primarily interested in doing a phenomenology of this consciousness. He wished to explore how the so-called personal was connected to the public and common world. 
Dewey goes on to say that the idealism of Mead's early years did not provide Mead with the answers he needed.

Even if it [idealism-M.A.] were true and were accepted as such, it did not explain how states of mind peculiar to an individual, like the first hypotheses of a discoverer which throw into doubt beliefs previously entertained and which deny objectivity to things that have been universally accepted as real objects, can function as the sources of objects which instead of being private and personal, instead of being merely "subjective," belong to the common and objective universe. (Dewey 1932: xxxvii)

11 One way in which Mead undermines a rigid dichotomy between the me and not-me, which James insists on in his Principles of Psychology, and between the private and public, involves articulating how the unique or novel, which is generated by the individual, becomes integrated into a wider community. ${ }^{12}$ Mead thought that societies depend on the novel responses of individuals to the accepted, to the given, in order to change, in a manner somewhat analogous to how eco-systems change if new, yet compatible, organisms or mutations are introduced. These novel responses are the terrain of what he came to call the "I." However, the question of overcoming a split between the so-called subjective and objective worlds is rendered even more challenging when the integration of the subjective and the objective, the personal and the public, is burdened with a parallel question: how does a self, which has a public dimension, maintain a unity or continuity in the face of the individual's own novel, personal, responses?

In part because of Mead's commitment to novelty, one solution that was not available to him in addressing the unity of the self is the notion that we have one basic fixed role or self that defines us. This is apparent if we contrast Mead with a pre-modern figure, Epictetus. ${ }^{13}$ According to Epictetus, we must all learn to play the role that Destiny has set for us.

Remember that you are an actor in a drama, which is as the playwright wishes; if the playwright wishes it short, it will be short; if long, then long; if the playwright wishes you to play a beggar, [it is assigned] in order that you good-naturedly play even that role; [and similarly] if [you are assigned to play] a disabled person, an

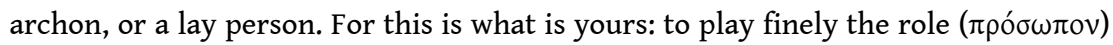
that is given; but to select [that role] itself is another's [i.e., the divine playwright]. (Epictetus, Ench.: 17) ${ }^{14}$

13 Commentators have considered roles as well played for Epictetus where an individual demonstrates universal virtues in carrying them out. But a question arises about whether success in roles should be understood solely in terms of universal virtues or whether there is something specific that allows a role to be successfully realized, for example, is Socrates or Hercules exhibiting some unique personal attributes, in addition to universal virtues? ${ }^{15}$ In a recent article on this topic, Brian Johnson tells us that scholars are divided on this question, with most assuming that universal virtues trump all else, which he refers to as the deflationary account. ${ }^{16}$ Johnson wants to argue for another position.

For Epictetus, then, our humanity appears to be a composite fact because we have a share

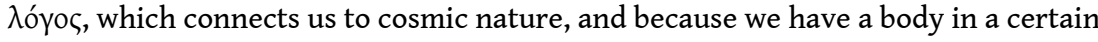
place and time, which means that we are susceptible to illness and a variety of material needs and that we must live among others and the consequences of their actions. As a result, our humanity cannot act as sole standard, as the deflationary model would have it, because it has many influences acting upon it; this multiplicity undermines the deflationary model. Thus, Epictetus does not say to agents "Here is a universal (human) 
standard, apply it to your differing circumstances," as the deflationary view suggests; rather, he says "The universe needs these different functions, so here are your specific stations." (cf. I 29.26-28, iii 22.4-8, and iii 24.94-95) ${ }^{17}$ ways for Epictetus, in addition to the presence of the logos, it is how well they play their roles. And it is role playing all the way down here, for there is no essential, particular, personal self behind a role. However, the fact that there are different roles is problematic for this model because although a particular station should ultimately define us - for example, Socrates as gadfly as opposed to Socrates as father - in our actual lives we are typically called on to perform more than one role. ${ }^{18}$ Can Socrates remain true to himself by being anything other than a gadfly or a wise man as deeply and as fully as possible? For Epictetus, it would seem not. And his Socrates appears to have much in common with Arendt's, in spite of the different reasons they might give for why consistency is to be prized.

This principle of agreement with oneself is very old; it was actually discovered by Socrates, whose central tenet, as formulated by Plato, is contained in the sentence: "Since I am one, it is better for me to disagree with the whole world than to be in disagreement with myself." From this sentence both Occidental ethics, with its stress upon being in agreement with one's own conscience, and Occidental logic, with its emphasis upon the axiom of contradiction, took their starting point. ${ }^{19}$

Although the unity here transcends the defining of oneself by a role, the price we pay for this transcendence would be too high for Mead, because it appears to require too much inner harmony. Nevertheless, it is difficult to dismiss the notion that at some level a self must be in agreement with itself, and this is true for Mead, as we shall see. While we don't yet know how Mead understands this agreement, we do know that because we are called on to play numerous roles, as well as confront our own novel responses, the solution of going more deeply into one role would not be a satisfactory solution to the problem of how to be in agreement with oneself. As for the question about the relationship of roles to each other, Mead would reply that a role is not a fully developed self. The self exists at a more complex level of organization. His whole analysis of the distinction between play and the game is based on this assumption. ${ }^{20}$ But if we are not unified by being a specific role all the way down, and if we have no essence, and if we are unable to appeal to an overarching logos to help define us, how then are we to understand the unity or continuity of the self?

The most recurrent solution that Mead gives to the question of the unity of the self involves viewing it as a function of a social group, so that the self is directly linked to the generalized other. In Mead's words, “The organized community or social group which gives to the individual his unity of self may be called 'the generalized other'." ${ }^{21}$ In these cases the self is the "me," and it can be understood as a complex set of behaviors or roles systemically organized. We can have multiple selves of this sort. There is an emphasis on the self as an object here, to which one can reflexively relate.

However, Mead now has an obvious problem, which to some extent parallels Epictetus's problem of multiple and potentially conflicting roles. How are we to understand the relationships between the different generalized others, the different social selves, which individuals presumably possess? Mead was of two minds about the notion of multiple personalities or selves. On the one hand, he thought multiple personalities quite normal, in the sense in which we have different "selves," identities, based on the organized

European Journal of Pragmatism and American Philosophy, VIII-1 | 2016 
groups or communities of which we are members. On the other hand, it should be seen as pathological when there is no connection between these personalities or selves. "Multiple personality is the breakup of the personality or self; there is no background for the organization of memory." 22

The notion of multiple personality, or what today is often referred to as Dissociative Identity Disorder (DID), is a hornet's nest. There are ongoing debates not only about its etiology, but about whether it should even be viewed as a distinct disorder. We need not concern ourselves with these debates. The question before us is which self breaks into different personalities or selves, according to Mead. Is it just one of a number of different social selves that fractures? To say that a multiple personality refers to a single fractured social self among a multitude of selves would indeed be a peculiar use of the phrase. It would localize the phenomenon too much. From Mead's vantage point, it would be to suggest that a self that one has in one social setting, say, as a member of a baseball team, could develop a multiple personality that would be confined to that setting. Further, we would then be left with the possibility of multiple multiple personality disorders if more than one of our social selves fractured, that is, if distinct social monads split in their own domains ${ }^{23}$ Mead's comments on multiple personality at minimum open the door to the possibility that there is a unity to the self that transcends individual generalized others and their social selves, a more comprehensive self that might split, that might become schizoid.

20 As a matter of fact, Mead argues in various places that selves generated in relationship to specific social groups can be united into more comprehensive unities. Here is a passage from his "1914 Lectures on Social Psychology."

There is a tendency still further to bring all of these different selves within a single self. We get that in the "abstract man," but there are others; "citizen" may include the other selves. This tendency to organize the different selves is essential for normal social conduct. There are relative degrees of dissociation in all of us. This self which takes in all the different selves is still the self that answers to the others. It is not the primary self but the composite. Out of such selves arise conceptions of the political man, the economic man, the object of charity, etc. ${ }^{24}$

21 Notice that Mead emphasizes that there is a tendency to unify or organize different selves into a single self, which can also be seen in the following remark, if we are willing to equate the notion of a "whole man" with a kind of self. "We legitimately have different selves over against different groups, and there is a natural organization among these which makes us a whole man. ${ }^{25}$ The notion of a more comprehensive or enlarged self is one that Mead discusses in different places, and not only in these lectures. It is often implied in his discussions of various communities. ${ }^{26}$ So one answer to what self might be split into multiple personalities is the composite self, a more comprehensive organization of elementary or localized selves. We will return to this suggestion shortly. But first notice how Mead contrasts the social secondary self with the primary self.

All the secondary selves - voter, church member, father - are related just as the different groups in society are related. The organization of this inner social consciousness is a reflex of the organization of the outer world. Secondly, there is a relation between these various secondary selves to the primary self which belongs to action. [...] An idea comes to us that does not come from the mouths of the selves that are presenting the case but from the primary self. The new attitude is a suggestion. We may be able to account for it after the act. ${ }^{27}$ (Emphasis added)

In introducing a primary self, as opposed to a secondary self, in these lectures, Mead leaves us with a further difficulty. It appears that not only does the unity of the self or 
selves exist on different levels, some more comprehensive than others, there are also two selves, primary and secondary. The primary self has attributes of what Mead came to refer to more consistently as the "I," while the secondary self can be equated with the "me." However, in spite of often treating the "me" and the self as synonymous - he asserts that the "I" is not the self, even though it shares attributes with the primary self ${ }^{28}$ - Mead also viewed the "I" and "me" taken together as the self, or more exactly, as "phases in the self," a phrase that he uses at the end of the passage below. In other words, the "I" and "me" are not seen as two selves, as the language of primary and secondary selves would suggest, but as phases of one self. ${ }^{29}$

Both aspects of the "I" and "me" are essential to the self in its full expression. [...] We speak of a person as a conventional individual; his ideas are exactly the same as those of his neighbors; he is hardly more than a "me" under the circumstances; his adjustments are only the slight adjustments that take place, as we say, unconsciously. Over against that there is the person who has a definite personality, who replies to the organized attitude in a way which makes a significant difference. With such a person it is the "I" that is the more important phase of the experience. Those two constantly appearing phases are the important phases in the self. (MSS: 199-200; emphasis added)

Recall that in addition to the selves currently under discussion, Mead referred to an unconscious self and claimed that the self could be equated with character. ${ }^{30}$ One simple way out of this morass of different selves would be to say that Mead or those who transcribed his lectures and edited his work were careless. Or that his appeal to different selves in different contexts only follows the pluralistic usage of the term that we found in James, and there is no notion of a meta-self in Mead's thought. But this is too easy. There are too many pieces of evidence that suggest that Mead actually did think of us as possessing some sort of meta or comprehensive self. At minimum we are unified as composite social selves, and if not unified at least potentially continuous in terms of the " $\mathrm{I}$ " and "me" phases in the self. Returning to that nagging question of how Mead understood multiple personalities will be of assistance in addressing the question of a more comprehensive or meta-self.

\begin{abstract}
The unity and structure of the complete self reflects the unity and structure of the social process as a whole; and each of the elementary selves of which it is composed reflects the unity and structure of one of the various aspects of that process in which the individual is implicated. [...] The phenomenon of dissociation of personality is caused by a breaking up of the complete, unitary self into the component selves of which it is composed, and which respectively correspond to different aspects of the social process in which the person is involved, and within which his complete or unitary self has arisen; these aspects being the different social groups to which he belongs within that process. (MSS: 144 ; emphasis added) ${ }^{31}$
\end{abstract}

So perhaps we are done. Even if we acknowledge that the self has phases of the "I" and "me," thus far it appears that the most comprehensive unity that we can find in Mead, if we include selves that are generated in relationship to past or imagined communities, is the composite unitary self, composed of component or elementary selves. ${ }^{32}$ Yet this does not appear to account for all that Mead has to say on the subject. It appears that there is a unity that is potentially more encompassing than the composite self, and digging deeper into Mead's views on multiple personality will assist in revealing it. 
each with distinct "I's" and "me's."

To a person who is somewhat unstable nervously and in whom there is a line of cleavage, certain activities become impossible, and that set of activities may separate and evolve another self. Two separate "me's" and "I's," two different selves, result, and that is the condition under which there is a tendency to break up the personality. (MSS: 143)

Mead immediately provides the following example, presumably to illustrate his point, but which actually opens up the path to another way of thinking about the self.

There is an account of a professor of education who disappeared, was lost to the community, and later turned up in a logging camp in the West. He freed himself of his occupation and turned to the woods where he felt, if you like, more at home. The pathological side of it was the forgetting, the leaving out of the rest of the self. This result involved getting rid of certain bodily memories which would identify the individual to himself. We often recognize the lines of cleavage that run through us. We would be glad to forget certain things, get rid of things the self is bound up with in past experiences. What we have here is a situation in which there can be different selves, and it is dependent upon the set of social reactions that is involved as to which self we are going to be. If we can forget everything involved in one set of activities, obviously we relinquish that part of the self. (MSS: 143)

To interpret the somewhat tortured language of these passages, it must first be noted that there are at least two usages of the word self. One refers to the interactive unity of an "I"-"me" as a self; the other to a more comprehensive self that can include memories associated with more than one "I"-"me" self. Mead appears to be suggesting that the professor's personality was split into two "I's and two corresponding "me's," and one organized set, one self, was lost when he settled in the West. Further, there is something wrong with this state of affairs. "The pathological side of it was the forgetting, the leaving out of the rest of the self. This result involved getting rid of certain bodily memories which would identify the individual to himself" (emphasis added). But wait. Why is there anything pathological about leaving behind a part of the (more comprehensive) self, which is associated with one "I"-"me"? Why is it not healthy to favor a new self - call it the Western Self - even it if involves forgetting a part of one's earlier (more comprehensive) self? Why is there a problem with losing memories or their connections, especially if they helped contribute to a personality split, in this case into two "I"-"me" selves?

Mead argues later in the passage that dropping memories is something that we might wish to do. "We would be glad to forget certain things, get rid of things the self is bound up with in past experiences." From this vantage point losing memories or no longer organizing them as a self need not be viewed negatively. In fact not retaining selves appears to be quite normal. We have different selves, which depend on social interactions and their concomitant memories, and we often drop or displace them when we enter new situations. Presumably the memories associated with them become reorganized or forgotten. Yet Mead referred to the professor's forgetting as pathological. From this perspective, it does not seem that we should divest ourselves of a dimension of who we were. Mead also tells us that if we "forget everything involved in one set of activities, obviously we relinquish that part of the self." Notice the last phrase here, "we relinquish that part of the self," which of course suggests that there was a more comprehensive self, and we have now lost part of it, as well as its former unity. ${ }^{33}$ So here is the conundrum: Mead's understanding of the social self would suggest that forgetting "parts" of the self, 
elementary selves, is at times to be expected, yet there is something pathological about the loss of memory associated with a split personality, although we are all in a certain sense split personalities with multiple social selves.

There is, of course, a danger of over interpreting a passage of this sort, especially given that it is drawn from an edited work. Nevertheless, I want to argue that Mead's language about the pathology of forgetting and his highlighting of bodily memories reflects something important about his views. The invocation of the life path of a specific person, with specific bodily memories, opens the door to another possibility for interpreting the unity of the self and for understanding the potentially pathological dimension of a split personality. ${ }^{34}$

In spite of Mead's claims about composite unified selves, there seems to be at least one lacuna in this account of the unity of the self, even if selves involve past or imagined communities, and it relates to our professor of education. Mead assumes that there is a unity to the self or the individual because he takes for granted that we have biographies.

What is accessible only to that individual, what takes place only in the field of his own inner life, must be stated in its relationship to the situation within which it takes place. One individual has one experience and another has another experience, and both are stated in terms of their biographies; but there is in addition that which is common to the experience of all. (MSS: 33; emphasis added)

For Mead, (auto)biography is uniquely human. Animals cannot have biographies. They certainly have memories but they cannot have biographies as we experience them. And the reason is obvious. Other animals are incapable of reflection, which depends on a conscious use of symbols..$^{35}$ Our lives can have a unity or continuity because we have the ability to use language to reflect on and organize our memories. We have the capacity to be aware and act, which are functions of the "I," and we can recall and reflect on the actions of the "I." When they are organized in relationship to a generalized other, they become a "me." When they are organized in relationship to memories that interest us, and perhaps anticipated and imagined futures, they become features of a biographical self, as do memories of affective experiences. ${ }^{36}$

We do inevitably tend at a certain level of sophistication to organize all experience into that of a self. We do so intimately identify our experiences, especially our affective experiences, with the self that it takes a moment's abstraction to realize that pain and pleasure can be there without being the experience of the self. Similarly, we normally organize our memories upon the string of our self. If we date things we always date them from the point of view of our past experiences. We frequently have memories that we cannot date, that we cannot place. (MSS: 135-6; emphasis added) ${ }^{37}$

Note Mead's words, "We do inevitably tend at a certain level of sophistication to organize all experience into that of a self," and "we normally organize our memories upon the string of our self. If we date things we always date them from the point of view of our past experiences." Although one could argue that he is talking about a specific social self here, a more natural interpretation is that he is defaulting to a set of assumptions about the individual having a biography, a self, that includes memories of the affective, as well as of actions and events.

Why would we unify our memories in this fashion? No doubt there is more than one reason, and the reasons may differ, as do narratives, from culture to culture. But from a Meadian vantage point, we can look to the continuous experiences of unity that we have owing to circumscribed and composite social selves. These selves would provide compelling exemplars for unifying other aspects of our experience. Perhaps narrative is 
in part born of a habit to unify experience that is grounded in the recurrent presence of organized social selves. ${ }^{38}$

It has become fashionable to speak of the self in terms of a narrative, a life-story. We find philosophers of different stripes, as well as psychologists, across a wide spectrum of traditions doing so. ${ }^{39}$ of course this does not prove that this is how we should best understand ourselves. It does, however, give Mead a viable option, one that would not undermine his other assumptions about the self. On the one hand, he could acknowledge an individual's traits and characteristics, which relate to our impulsive and habitual sides, without claiming that they are a source of unity in and of themselves, because they are not systemically organized. On the other hand, he can still argue that social groups and communities provide the systemic organization necessary for giving rise to selves. But he does not have to stop here. He can also say that individuals link selves together, along with their novel responses to events, to generate biographies, life-stories, narratives. An inability to weave together memories, selves, and the transitions between them leads to a pathological splitting of the personality, to an incoherent biography, to ultimately no biography at all, which would certainly make being in agreement with oneself an evanescent phenomenon.

Recall the problem that Dewey claimed had engaged Mead in his earlier years: the relationship between private experience, the subjective, and that which is public, objective. Mead went on to provide a genetic account of the self that sought to show how private perspectives are known through reflection, a capacity that arises through a social process. He also sought to provide an account of the mechanisms for integrating novel events into existing systems, ${ }^{40}$ which relates to the issue of how "subjective" perspectives can become "objective" ones, that is, how that which is novel and unique can become conceptually accessible to a community. But without considering personal narratives, a significant portion of private experience, which can relate to public life in various ways, would be difficult to fathom. Further, without a "biographical self" it would be difficult to make sense of some of the ways in which Mead speaks about self-realization and selfassertion, for example, our desire "to recognize ourselves in our differences from other persons. [...] [which may include-M. A.] manners of speech and dress, to a capacity for remembering, to this, that, and the other thing - but always to something in which we stand out above people." ${ }^{\prime 1}$ It would also be difficult to explain the weight that Mead appears to give to the connection between the obligation to keep one's word and selfrespect in the quotation that began this article.

My suggestion is that Mead had an undeveloped narratological account of the self that allowed him to make claims that were in line with his rather robust sense of what is right and proper for a human being to achieve, at least in the modern Western world. Viewing the self in terms of narrative need not challenge Mead's pluralistic usages of the term self. It complements them by providing an overarching framework that allows us to make sense of how memories and multiple selves are bound together, supplying a unity more comprehensive than the composite social self. It also assists us in making sense of Mead's claims about the pathological nature of certain kinds of split personality. Whether Mead's systemic orientation to the self, combined with his sensitivity to novelty, would provide sufficient tools for the development of a satisfying narratological account of the self is interesting question. It is a question for another article, as is the question of whether narrative in its various incarnations, along with other aspects of the individual spelled out by Mead, are sufficient to supply us with a satisfactory account of personhood. 


\section{BIBLIOGRAPHY}

ABoulafia M., (2011), “Through the Eyes of Mad Men: Simulation, Interaction, and Ethics," European Journal of Pragmatism and American Philosophy, III, 2.

ARENDT H., (1993), "The Crisis in Culture: Its Social and Its Political Significance," in Between Past and Future, New York, Penguin.

cоoK G. A., (1993), George Herbert Mead: The Making of a Social Pragmatist, Urbana and Chicago, University of Illinois Press.

DEWEY J., (1932), "Prefatory Remarks," in G. H. Mead, The Philosophy of the Present, edited with an Introduction by Arthur E. Murphy, La Salle, IL, Open Court.

JAMES W., (1950 [1890]), The Principles of Psychology, Volume One, New York, Dover Publications.

JOAS H., (1985), G. H. Mead: A Contemporary Re-examination of his Thought, trs. Raymond Meyer, Cambridge, MA, The MIT Press.

Johnson B. (2012), "Socrates, Heracles and the Deflation of Roles in Epictetus," Ancient Philosophy $32,125-45$.

MCADAMS D. P., (2009), “The Moral Personality,” in Narvaez D. \& Lapsley D. K., (eds.), Personality, Identity, and Character: Explorations in Moral Psychology, Cambridge, Cambridge University Press. MEAD G. H., (1964 [1913]), “The Social Self,” in Selected Writings: George Herbert Mead, edited by Andrew J. Reck, Chicago, University of Chicago Press.

MEAD G. H., (1932b), The Philosophy of the Present, edited with an Introduction by Arthur E. Murphy, La Salle, IL, Open Court.

MEAD G. H., (1934), Mind, Self and Society: from the Standpoint of a Social Behaviorist, edited with an Introduction by Charles W. Morris, Chicago, University of Chicago Press.

MEAD G. H., (1982), "1927 Lectures in Social Psychology," in The Individual and the Social Self: Unpublished Work of George Herbert Mead, edited by David L. Miller, Chicago, The University of Chicago Press.

MEAD G. H., (1982b) "1914 Lectures in Social Psychology," in The Individual and the Social Self: Unpublished Work of George Herbert Mead, edited by David L. Miller, Chicago, The University of Chicago Press.

MILLER D., (1973), George Herbert Mead: Self, Language, and the World, Austin, Texas, University of Texas Press.

SHALIN D., (2015), “Making the Sociological Canon: The Battle Over George Herbert Mead's Legacy ," The American Sociologist, 45, 4, 3-30.

\section{NOTES}

1. G. H. Mead, (1934), Mind, Self and Society. Henceforth, MSS. 
2. Noteworthy books that address Mead's philosophy and understanding of the self include: Cook 1993; Joas 1985; Miller 1973. For additional resources, see the bibliography for the article, "George Herbert Mead," in the on-line Stanford Encyclopedia of Philosophy.

3. Mead begins his article, "The Social Self," with the following assertion. "Recognizing that the self cannot appear in consciousness as an 'I,' that it is always an object, i.e., a 'me,' I wish to suggest an answer to the question, What is involved in the self being an object?" (1964: 142).

4. On the relationship between the novel "I" and the conventional "me," see MSS: 209. Mead claims, "The 'I' both calls out the 'me' and responds to it. Taken together they constitute a personality as it appears in social experience. The self is essentially a social process going on with these two distinguishable phases. If it did not have these two phases there could not be conscious responsibility, and there would be nothing novel in experience" (MSS: 178).

5. Mead tells us that, "It is a structure of attitudes, then, which goes to make up a self, as distinct from a group of habits. We all of us have, for example, certain groups of habits, such as the particular intonations which a person uses in his speech. [...] There are whole bundles of such habits which do not enter into a conscious self, but which help to make up what is termed the unconscious self" (MSS: 163). Regarding the relationship of the body to the self, Mead states, "It [the self-M.A.] is a social entity that must be related to the entire body, and only insofar as the self is related to the body is it related to the environment. [...] The self involves a unity; it is there in the social process, but there is no self unless there is the possibility of regarding it as an object to itself. It is the center about which the individual is organized, and the body is an integral part of the self. [...] When we try to regard ourselves independently of our organisms [...] we may be put into an asylum. [...] We are thus tied to the body insofar as we have a self" (Mead 1982: 148).

6. Mead (1964: 147).

7. See Mead's praise of James's chapter on the self in, "Social Psychology as Counterpart to Physiological Psychology," in Mead (1964: 96).

8. James (1950: 292).

9. For example, regarding self-assertion, Mead states, "We have, of course, a specific economic and social status that enables us to so distinguish ourselves. We also have to some extent positions in various groups which give a means of self-identification, but there is back of all these matters a sense of things which on the whole we do better than other people do. It is very interesting to get back to these superiorities, many of them of a very trivial character, but of great importance to us. We may come back to manners of speech and dress, to a capacity for remembering, to this, that, and the other thing - but always to something in which we stand out above people" (MSS: 205). It should be noted that Mead stresses that superiority need not be understood in a crude hierarchical manner. "This sense of superiority does not represent necessarily the disagreeable type of assertive character, and it does not mean that the person wants to lower other people in order to get himself into a higher standing" (MSS: 205).

10. See, Aboulafia 2011.

11. John Dewey (1932: xxxvi).

12. At the close of the chapter on "The Stream of Thought" in the Principles of Psychology, James discusses the split between the "me" and the "not-me." See James (1950: 289).

13. At times it appears as if Mead adheres to a position similar to Epictetus's, but we will see that this is not the case. For example, Mead tells us that, "The proudest assertion of independent selfhood is but the affirmation of a unique capacity to fill some social role." George Herbert Mead, "National-Mindedness and International-Mindedness," in Mead (1964: 357).

14. Brian Johnson (2012: 125-45). This is Johnson's translation and interpolations, p. 125.

15. Johnson (2012: 126).

16. Johnson (2012: 126).

17. Johnson (2012: 136).

European Journal of Pragmatism and American Philosophy, VIII-1 | 2016 
18. Epictetus "is grappling with an important philosophic problem about how the unity of Stoic virtue maps onto the messy pluralities of real life. He deploys the human role to capture the unity of virtue and specific roles to capture the particularities of daily life" (Johnson 2012: 144).

19. Hannah Arendt (1993: 220) is citing Plato from the Gorgias: 482. For Arendt, agreement with oneself involves an inner dialog. The voices engaged in this dialog must not remain in contradiction, but how much tension can still exist between them, when harmony or agreement is achieved, is a topic for another paper.

20. MSS: 149-64.

21. MSS: 154. Mead continues, "The attitude of the generalized other is the attitude of the whole community. Thus, for example, in the case of such a social group as a ball team, the team is the generalized other in so far as it enters - as an organized process or social activity - into the experience of any one of the individual members of it" (MSS: 154; emphasis added).

22. Mead (1982: 163). Notice that Mead is equating "the personality" and "self" here. He does this in other places, see, for example, p. 210 and note 31 below.

23. It's worth noting that it is possible to lose a self that we once had, while retaining sensible experiences that were once associated with this self. In such a situation the individual "becomes a different personality." "If we had no memory which identifies experiences with the self, then they would certainly disappear so far as their relation to the self is concerned, and yet they might continue as sensuous or sensible experiences without being taken up into a self. That sort of a situation is presented in the pathological case of a multiple personality in which an individual loses the memory of a certain phase of his existence. Everything connected with that phase of his existence is gone and he becomes a different personality. The past has a reality whether in the experience or not, but here it is not identified with the self - it does not go to make up the self" (MSS: 170; emphasis added).

24. Mead (1982b: 77-8). According to Dmitri Shalin these lectures were actually given in 1912. See, Shalin 2015.

25. Mead (1982b: 74). The term "natural" here does not refer to the biological. Mead is addressing how inner social consciousness relates to "the organization of the outer world" (Ibid.: 74).

26. For example, in MSS: 265, Mead states, "He may belong to a small community, as the small boy belongs to a gang rather than to the city in which he lives. We all belong to small cliques, and we may remain simply inside of them. The 'organized other' present in ourselves is then a community of a narrow diameter. [...] [T] he boy gets a larger self in proportion as he enters into this larger community."

27. Mead (1982b: 74-5).

28. See, for example, the beginning lines of "The Social Self" above, note 3.

29. See, note 4, above. Mead sought to understand the relationship of the spontaneous responses of the "I" to the organized "me." In my view, it can best be understood in light of Mead's account of sociality and emergence. For Mead, systems manage to adjust to novel events, for example, when a new species is introduced into an eco-system. There is a state betwixt and between an old system and a new one, which Mead refers to as one of sociality, using the term in a specialized sense. The "me" may be thought of as a system. When the "I" acts in a novel way, the organized "me" may in reaction undergo modification. If it does, a new unified system, a new "me," emerges. See, Mead on sociality and emergence in The Philosophy of the Present, for example, Mead 1932b: 1-2, 47-9.

30. See, above, p. 203 and notes 5 and 6.

31. Mead is not distinguishing between "personality" and "self" here and I am following his lead.

32. Mead notes that, "A multiple personality is in a certain sense normal, as I have just pointed out. There is usually an organization of the whole self with reference to the community to which we belong, and the situation in which we find ourselves. What the society is, whether we are living with people of the present, people of our own imaginations, people of the past, varies, of course, with 
different individuals. Normally, within the sort of community as a whole to which we belong, there is a unified self, but that may be broken up" (MSS: 142-3; emphasis added).

33. And when Mead says that "We often recognize the lines of cleavage that run through us," to whom does the "we" refer? To one among many social selves? But such selves would not be in position recognize this cleavage. They are objects of which we are aware. Perhaps the "we" refers to the "I" in its role as a "consciousness of" the "me" as an object, which is one of its functions for Mead? But this would presume that the "I" has the capacity to contrast various social selves, because it possesses some sort of macroscopic overview. There may be something to this, although this is not the way in which the "I" is typically presented. It is first and foremost the sphere of action and the impulsive, and might be thought of as related to the "me" as matter to form. "A self is a composite or interaction of these two parts of our natures - the fundamental impulses which make us co-operating neighbors and friends, lovers and parents and children, and rivals, competitors, and enemies; on the other side the evocation of this self which we achieve when we address ourselves in the language which is the common speech of those about us. We talk to ourselves, ask ourselves what we will do under certain conditions, criticize and approve of our own suggestions and ideas, and in taking the organized attitudes of those engaged in common undertakings we direct our own impulses. These two parts are the matter and the form of the self, if I may use Aristotelian phraseology" (Mead 1964, "National-Mindedness and International-Mindedness," 357-8).

34. Thus far we have found that for Mead: 1 ) the "me" is the cognizable social self, 2) there is a composite self, which operates at a higher level of unity than more elementary social selves, 3) the "I" is the home of the impulsive, spontaneous, and the novel, 4) the self is the "I" and the "me" in process, 5) the spontaneous or novel responses of the "I" can be integrated into a "me," creating a new "me," which involves the processes of sociality and emergence (see, above, note $29), 6)$ the self is not the body but there is an unconscious self which is made up of bundles of habits, and habits are tied to the body, and 7) the self can be referred to as character. Is this a comprehensive list of factors that relate to the question of the multiplicity of selves and the self's unity? In addition, there is also the possibility that the "I" might be the source of an encompassing meta-self. This alternative would require that the "I" itself be unified, but this is no longer Mead, at least not the Mead who can also speak of the "I" as the home of the spontaneous, the impulsive, and the source of novelty. Even granting him a great deal of leeway in describing the various functions of the "I," to appeal to the "I" as the source of a meta-self strains credulity; the "I" as a deus ex machina. This said, if the I is viewed as a "stand-in" for the act, it can be viewed as unifying experience. But this is as an act, not as a meta-self. See MSS: 279.

35. MSS: 122-3, 132-4.

36. Mead's comments on history and biography are worth noting. "History is nothing but biography, a whole series of biographies; and yet all of these social sciences deal with individuals in their common characters; and where the individual stands out as different he is looked at from the point of view of that which he accomplishes in the whole society, or in terms of the destructive effect which he may have. But we are not primarily occupied as social scientists in studying his experience as such" (MSS: 36-7).

37. This passage begins, "One must, of course, under those conditions, distinguish between the experience that immediately takes place and our own organization of it into the experience of the self. One says upon analysis that a certain item had its place in his experience, in the experience of his self" (MSS: 135).

38. For Mead, we certainly have non-reflective, non-self-conscious experiences. Much of our lives are lived in this fashion, in a world of pre-reflective habits. But we also regularly experience having a self.

39. See, for example, McAdams 2009, location 198-207, Kindle Edition.

40. See note 29 above. 
41. MSS: 205. It is possible to interpret Mead as referring only to self-respect and differences from others in a specific community, but this is unlikely given rest of this passage. See note 9 above.

\section{ABSTRACTS}

After more than seventy-five years of scholarship on Mead's notion of the self, commentators still debate the meaning of the term. There are those who argue that it should be understood primarily as a socially constructed "me," while others claim that the self is a combination of the spontaneous "I" and the "me." In addition, there are those who emphasize facets of the self that do not fit neatly into either of these two camps. Support for various interpretations of the self can in fact be found in Mead's work. This article addresses Mead's uses of the term, guided by two questions: what kinds of unity or continuity are characteristic of selves? And is there a form of unity - a "meta-self" - that can encompass the types of selves that we find in Mead? In response to the second question, it is demonstrated that Mead had a narrative account of the self, one that has the potential to incorporate different kinds of selves, although Mead left his account underdeveloped.

\section{AUTHOR}

\section{MITCHELL ABOULAFIA}

Manhattan College

mitchell.aboulafia[at]manhattan.edu 